A N N A L E S

UNIVERSITATIS M ARIAE CURIE-SKŁODOWSKA

LUBLIN - POLONIA

VOL. LXIII, 2

SECTIO C

2008

\title{
ANDRZEJ KOWNACKI
}

Institute of Nature Conservation PAS,

31-120 Kraków, al. A. Mickiewicza 33,

e-mail: kownacki@iop.krakow.pl

\section{Kryon - communities of high mountain streams}

Kryon - zoocenozy wysokogórskich potoków

\section{SUMMARY}

High mountain streams, flowing above the upper forest line, arise from the meltwater of glaciers, permanent snow fields and high mountain lake-outlet streams and temporary springs

Larvae of Diamesa (Chironomidae, Diptera), mainly Diamesa steinboecki group, Diamesa latitarsi group dominate among macroinvertebrates developing in these streams. Other fauna groups, like Ephemeroptera do not occur or are represented by single individuals of Trichoptera and Plecoptera. Biodiversity is here very small, 2-10 taxons, density very low, below 1500 individuals/ $\mathrm{m}^{2}$. In lower parts of these streams macroinvertebrate communities differentiate depending on hydrological conditions. In high mountain lake-outlet streams Simuliidae (Diptera) dominates. Inflow strong springs to high mountain stream (in the Tatra Mts. at the upper forest boundary) changing the composition, structure, and abundance of community and mayflies Baetis and Rhithrogena, and Orthocladiinae (Chironomidae) dominate. It should be mentioned, however, that streams flowing out of springs are sometimes met also at high altitude up to $3000 \mathrm{~m}$ a.s.l. Their fauna differs from that of high mountain streams. Larvae of Diamesa latitarsis group dominate here as well, but there are also numerous larvae of Orthocladiinae and some Trichoptera and Plecoptera but Ephemeroptera do not occur. Biodiversity is here much higher (15-30 taxons) and density above 2500 individuals $/ \mathrm{m}^{2}$.

Dissimilarity of macroinvertebrates in high mountain streams led to their separation from classical zone system of running waters crenon $\rightarrow$ rhithron $\rightarrow$ potamon and to formation of new zone kryon. 


\section{STRESZCZENIE}

Potoki wysokogórskie płynące powyżej górnej granicy lasu powstają z lodowców, płatów wiecznego śniegu, jezior wysokogórskich lub okresowych drobnych wycieków. Badania prowadzono w potokach Tatr i porównawczo w górach Szwedzkiej Laponii, Alpach i Kaukazie. Rozwijające się w tych potokach zespoły makrobezkręgowców charakteryzują się dominacją larw z rodzaju Diamesa (Chironomidae, Diptera), głównie Diamesa steinboecki, Diamesa gr. latitarsis. Pozostałe grupy fauny nie występują, np. jętki (Ephemeroptera), lub są reprezentowane przez pojedyncze osobniki chruścików (Trichoptera), widelnic (Plecoptera). Bioróżnorodność jest tu bardzo mała, 2-10 taksonów, zagęszczenie niskie, nieprzekraczające 1500 osobników $/ \mathrm{m}^{2}$. W dolnych odcinkach tych potoków zoocenozy się różnicują w zależności od warunków hydrologicznych. W potokach płynących poniżej jezior wysokogórskich dominują Simuliidae (Diptera). Często na pewnej wysokości (w Tatrach przy górnej granicy lasu) do potoku dopływają źródła i począwszy od tego momentu, zmienia się struktura, skład i liczebność zespołu. Dominują tu jętki z rodzaju Baetis i Rhithrogena oraz Orthocladiinae (Chironomidae). Należy jednak nadmienić, że również powyżej górnej granicy, na dużych wysokościach (do 3000 m n.p.m.), spotyka się potoki biorące początek ze źródeł. Ich fauna różni się zarówno od omawianych potoków wysokogórskich, jak i źródliskowych. Nadal dominują larwy Diamesa gr. latitarsis, ale spotyka się również bardzo liczne larwy Orthocladiine z rodzajów Orthocladius (Euorthocladius), Tvetenia oraz widelnice i chruściki, brak natomiast jętek. Znacznie wyższa jest tu bioróżnorodność (15-30 taksonów) i zagęszczenie (powyżej 2500 osobników $/ \mathrm{m}^{2}$ ).

Odmienność zespołów makrobezkręgowców w potokach wysokogórskich spowodowała wydzielenie ich z klasycznego strefowego podziału wód płynących crenon $\rightarrow$ rhithron $\rightarrow$ potamon i stworzenie nowego zespołu kryon.

Key words: high mountain, stream, kryon, zonation, macroinvertebrate, communities

\section{INTRODUCTION}

Longitudinal changes in ecological conditions from the headwaters to the mouth of the river system are profound, especially over large elevation gradients, as are the attendant changes in the structural and functional attributes of lotic macroinvertebrate communities. Illies (1961) and Illies, Botosaneanu (1963) proposed a world-wide classification system for lotic waters and introduced the terms crenon (spring source), rhithron (torrent and mountain river) and potamon (large river) to divide lotic system into three major zones, each with additional subdivision. Most river systems originate as springs. But in mountains with maximum elevations exceeding the permanent snowline, yet an additional zone must be added. Streams arising from the meltwater of glaciers, permanent snow fields and high mountain lake-outlet and temporary springs form a distinct macroinvertebrate communities, the kryon (Steffan 1971, Kownacka, Kownacki 1972).

Studies on the fauna of high mountain streams were initiated by Steinböck (1934) and Thienemann (1936) in the Alps seventy years ago. However, information on high mountain stream and its macroinvertebrate communities are still incomplete.

The aim of this work was to present a zonal distribution of the macroinvertebrate communities in the different types of the high mountain streams and the influence of hydrological, physical and hydrochemical factors upon the composition and numbers of the invertebrates. 


\section{STUDY AREA AND METHODS}

The study was carried out mainly in the High Tatra Mts (I) on the Mnichowy Potok and Sucha Woda streams (the Tatra National Park, Poland) and comparatively in the Swedish Lappland (II) on the Kaskasatjåkka, Tarfalajåkka and Ladtjojåkka streams near Kebnekaise mountain (about 140 $\mathrm{km}$ beyond the Arctic Circle), in the Alps (III) on the Rio Plima and its tributaries Rio Madricio and Rio Gioveretto, (the Parco Nacionale della Stelvio, South Tirol, Italy) and in the Caucasus (IV) on the Upper Terek River (the South Ossetia, Georgia) in the glacial, spring-fed and lake-outlet streams.

(I) The Mnichowy stream is the outlet of the Zadni Mnichowy Stawek pool, originating from the meltwater of permanent snow fields, and situated at an altitude of 2075 to $1840 \mathrm{~m}$. a.s.l. The length of this stream is $550 \mathrm{~m}$., with mean channel slope of $427 \%$. Temperature of water is very low $\left(1-4.5^{\circ} \mathrm{C}\right)$ and the water is transparent.

Investigation was carried out in the outlet from Zmarzły Staw Gąsienicowy Lake $(1851 \mathrm{~m}$ a. s. 1.), the Czarny Potok stream which is the outlet of Czarny Staw Gąsienicowy Lake (1619 m a. s. 1.), the Sucha Woda stream and the Cicha Woda (Cichowiańska Woda) stream which inflow to the Poroniec stream at an altitude of $770 \mathrm{~m}$ a. $\mathrm{s}$. 1. The total length of this streams is $15.5 \mathrm{~km}$, with mean channel slope of $68 \%$. The water was transparent.

(II) Investigation was carried out in glacier stream Kaskasatjakka which flows from under the Kaskasatglaciären (1340 m. a.s.l.), the Tarfalajåkka stream which is outlet of the Tarfalkasjön lake (1168 m. a.s.1.), and lower reach of the Ladtjojåkkaj river (500-560 m. a.s.1.). On altitude $1020 \mathrm{~m}$. the Tarfalajåkka stream flows across a small pool and on $1000 \mathrm{~m}$ joins with glacial stream flowing out of the Storglaciären. The Ladtjojåkka river flows across Ladtjojaure Lake. In the glacier stream water was turbid, and in the outlet of lakes and the Ladtjojakkka river water was transparent. The total length of Tarfalajåkka stream is $9.5 \mathrm{~km}$, with mean channel slope of $82 \%$ and length of investigation reach of the Ladtjojåkka river was $13.5 \mathrm{~km}$ long with slope 4.4\%.

(III) The Rio Plima river, the right tributary of the Fiume Adige river, flows across a Val Martello valley. It arises from Vederetta Lunga glacier at $2700 \mathrm{~m}$ a.s.l. and flows across cobbles - pebbles postglacial terraces covered with rock rubble. At the altitude of $2300 \mathrm{~m}$ a.s.l. it flows into deep canyon, which ends at $1900 \mathrm{~m}$. Then it flows across forest valley. At the altitude of $1850 \mathrm{~m}$ a great dam reservoir Lago Gioveretto was built. Down from the village Martel (1000-1200 m.) the stream flows across forest areas or fields, meadows and orchards. Along this reach the water level is much lower because the water is used for watering orchards. After $26.5 \mathrm{~km}$, at the altitude of $660 \mathrm{~m}$ a.s.l. the stream flows into Fiume Adige. The average channel slope is here 82.3\%.

Rio Gioveretto, the right tributary of Rio Plima, arises from Vederetta dello Gioveretto glacier at the altitude of $2750 \mathrm{~m}$ a.s.l. First it flows along postglacial valley covered with boulders, then it flows steeply down the moraine slope into the next terrace covered with rubbles and stones, sometimes with high mountain meadows. Below $2200 \mathrm{~m}$ a.s.l. it flows across the thick spruce and larch forest. Then at the altitude of $1850 \mathrm{~m}$ a.s.l. it flows into Lago Gioveretto reservoir. The length of this stream is $3 \mathrm{~km}$, with mean channel slope $300 \%$.

Rio Madriccio, the left tributary of Rio Plima, arises from melting snow patches and springs flowing from under a moraine, then it flows steeply down the glacial valley in a river bed cut into moraine layers covered with big rock blocks. Starting from $2200 \mathrm{~m}$ a. s. 1. it falls in cascades steeply down across spruce and larch forest, sometimes across meadows. It flows into Rio Plima at $2000 \mathrm{~m}$ a.s.1.. The length of this stream is $5 \mathrm{~km}$, with mean channel slope $170 \%$.

(IV) Observations of the fauna distribution was carried out along the course of the Upper Terek river and its glacial tributary Suatisi. The Suatisi stream arises from glacier at $2800 \mathrm{~m}$ a.s.1. and joins Terek river at $2550 \mathrm{~m}$. a.s.l. The length of this stream is about $2 \mathrm{~km}$, with mean channel slope 
$125 \%$. The length of the investigated reach (on altitude $1800-2250$ m. a.s.1.) of the Terek River is $33 \mathrm{~km}$ and mean chanel slope $13.6 \%$. In both streams water was turbid.

Samples of invertebrates were collected with hand net $22.5 \times 22.5 \mathrm{~cm}$, covered with gauze 0.3 $\mathrm{mm}$ in mesh diameter. The material obtained was calculated per $1 \mathrm{~m}^{2}$ of stony bottom. Result is presented as percentage domination. On the basis of values of dominance 3 groups were distinguished: dominant taxa $>10 \%$, subdominant $1-9.9 \%$ and adominant $<1 \%$. In the table only dominant taxa are presented.

\section{RESULTS}

(I) The Tatra streams

In the upper part (1950-2070 m a.s.1.) of the Mnichowy stream the macroinvertebrate community was similar to that in the glacial streams. The species $D i$ amesa steinboecki, D. nowickiana and D. latitarsis were dominating (Tab. 1). In the lower part (1900 m a.s.1.) of this stream, apart from species of the genus Diamesa, Parorthocladius nudipennis was dominating and some specimens of Diptera from families of Simuliidae (Prosimulium sp.), Blephariceriade, Tipulidae and Plecoptera (Leuctra sp), Trichoptera (Drusus monticola), Turbelaria (Planaria alpina) were found. Ephemeroptera was absent.

The fauna in the Sucha Woda stream was represented mainly by insects larvae, especially of Chironomidae (Diptera) (Tab. 2). Above $1550 \mathrm{~m}$. the dominant taxa were Diamesa latitarsis group and in outlet of the Czarny Staw lake also Simuliidae - Prosimulium. At the altitude 1550-1000 m. Eukiefferiella minor and Parorthocladius nudipennis (Chironomidae), as well as Baetis alpinus and Rhithrogena loyolaea (Ephemeropptera) predominate. Below $1000 \mathrm{~m}$ the dominant taxa were larvae Orthocladius (Euorthocladius) rivicola group and Simuliidae. In reach of the Sucha Woda stream which dry up temporarily (about $1000 \mathrm{~m}$ ), immediately on the resumption of flow, juvenile larvae Eukiefferiella cyanea and Diamesa sp., appear in masses, but from July until the end of the period of flow, nymphs of mayflies Baetis alpinus group were the first dominant. In autumn larvae of Diamesa latitarsis were an important faunistic element.

(II) The Swedish Lapland streams

In the glacial stream Kaskasatjåkka (Tab. 3), at the foot of the glacier, only single larvae of Diamesa latitarsis group and juvenile stage Diamesa were found. Below the Lake Tarfalasjön community was completely reconstructed. The first dominant were larvae Pseudodiamesa sp., the second Diamesa ursus; an important subdominant were larvae Orthocladius (E.) rivicola group., whereas larvae of Diamesa latitarsis group were scarce. At the next site community changed again. The first dominant were larvae of Orthocladius (E.) rivicola group, the second Diamesa sp. I, quite numerous were Simuliidae - Prosimulium ursinum. The tributary of big, turbid, stream from Storglaciären rapidly changed compo- 
Table 1. Characteristics of the Mnichowy stream and altitudinal zonation of macroinvertebrate communities (bold figure - dominant $10-100 \%$, + adominant $>1 \%$, A - alpine zone)

\begin{tabular}{|l|c|c|c|c|c|}
\hline \multicolumn{1}{|c|}{ Sites } & 1 & 2 & 3 & 4 & 5 \\
\hline Altitudae (m a.s.1.) & 2075 & 2060 & 2025 & 1890 & 1850 \\
\hline Zone & $\mathrm{A}$ & $\mathrm{A}$ & $\mathrm{A}$ & $\mathrm{A}$ & $\mathrm{A}$ \\
\hline Water temperature ${ }^{0} \mathrm{C}$ & $1.1-3.5$ & 4.5 & $3.7-4.0$ & $3.0-4.5$ & $2.5-6.5$ \\
\hline $\mathrm{pH}$ & 6.2 & & & & 6.2 \\
\hline Diamesa steinboecki & $\mathbf{2 5}$ & $\mathbf{1 5}$ & $\mathbf{2 7}$ & $\mathbf{2 9}$ & + \\
\hline Diamesa latitarsis & $\mathbf{1 1}$ & $\mathbf{2 7}$ & $\mathbf{1 8}$ & $\mathbf{3 1}$ & $\mathbf{2 2}$ \\
\hline Diamesa nowickiana & $\mathbf{2 3}$ & $\mathbf{2 1}$ & $\mathbf{3 2}$ & 3.2 & \\
\hline Diamesa sp. (gr. zernyi) & $\mathbf{1 7}$ & 4.5 & 5.2 & 6.2 & 4.7 \\
\hline Pseudokiefferiella parva & 9.7 & $\mathbf{1 9}$ & $\mathbf{1 4}$ & 1.6 & 1.0 \\
\hline Parorthocladius nudipennis & & & & + & $\mathbf{3 1}$ \\
\hline
\end{tabular}

Table 2. Characteristics of the Sucha Woda stream and altitudinal zonation of macroinvertebrate communities, (bold figure - dominant 10-100\%, + adominant $>1 \%$, A - alpine zone, D - dwarf pine zone $\mathrm{F}$ - forest zone)

\begin{tabular}{|c|c|c|c|c|c|c|c|c|c|}
\hline & $\mathrm{ZP*}$ & \multicolumn{3}{|c|}{ Czarny Potok } & \multicolumn{4}{|c|}{ Sucha Woda } & Cicha \\
\hline Sites & 1 & $2 * *$ & $3 * * *$ & 4 & 5 & 6 & $7 * * * *$ & 8 & 9 \\
\hline Altitudae (m a.s.1.) & 1850 & 1600 & 1500 & & & & 1000 & & 780 \\
\hline Zone & $\mathrm{A}$ & $\mathrm{D}$ & $\mathrm{D}$ & $\mathrm{F}$ & $\mathrm{F}$ & $\mathrm{F}$ & $\mathrm{F}$ & $\mathrm{F}$ & $\mathrm{F}$ \\
\hline Water temperature ${ }^{0} \mathrm{C}$ & $0.9-6.9$ & $4.5-12.3$ & $2.4-9.4$ & $1.0-9,1$ & $1.4-7.9$ & $0.4-5.3$ & $0.5-9.4$ & $1.2-10$ & $0.2-13$ \\
\hline $\mathrm{pH}$ & $6.3-6,4$ & $6.0-6.5$ & $6.2-6.5$ & $6.3-6.6$ & $6.4-7.0$ & $6.6-7.4$ & $6.9-7.4$ & $7.4-8.3$ & $7.0-8.5$ \\
\hline Conductivity $\mu \mathrm{S}$ in $18^{0}$ & 17 & $18-22$ & $23-96$ & $21-26$ & $31-69$ & & & $69-185$ & $118-215$ \\
\hline Calcium Ca mg/dm ${ }^{3}$ & $2.4-4.4$ & $2.6-4.3$ & $2.9-4.9$ & $3.3-5.0$ & $5.7-8.6$ & & & $13-33$ & $20-41$ \\
\hline $\mathrm{O}_{2} \%$ & $79-81$ & $83-85$ & $82-86$ & $82-86$ & $84-88$ & 84-89 & & 89-92 & $79=94$ \\
\hline Diamesa latitarsis gr. ${ }^{1}$ & 48 & 12 & + & + & 1.5 & 4.5 & 3.6 & + & + \\
\hline Protonemura sp. & 10 & + & 3.0 & 3.1 & 1.4 & 1.2 & + & + & 1.0 \\
\hline Prosimulium sp. & 8.7 & 27 & + & 1.0 & 1.8 & 5.6 & 9.6 & 12 & 15 \\
\hline Eukiefferiella minor & 1.5 & 4.8 & 27 & 10 & 1.3 & 3.6 & + & 4.5 & 3.2 \\
\hline Diamesa spp. (juv.) & 1.4 & + & + & + & 3.8 & 3.2 & 12 & 4.0 & 2.9 \\
\hline Tvetenia bavarica gr. $^{2}$ & + & 15 & 3.8 & 8.9 & 1.7 & 1.8 & 2.3 & 3.1 & 4.0 \\
\hline Nais variabilis & + & 14 & + & + & + & 2.0 & + & & + \\
\hline Baetis alpinus gr. ${ }^{3}$ & & + & 17 & 9.5 & 13 & 10 & 23 & 3.4 & 3.1 \\
\hline Parorthocladius nudipennis & 3.1 & + & 13 & 12 & 30 & 16 & 1.4 & 2.0 & 1.4 \\
\hline Orthocladius (E.) gr. rivicola & + & + & + & 1.1 & 2.2 & 9.5 & 5.3 & 27 & 31 \\
\hline Eukiefferiella cyanea & & & & & & + & 28 & + & + \\
\hline $\begin{array}{l}\text { Mean density ind. } / \mathrm{m}^{2} \\
\text { (in thousand) }\end{array}$ & 0.7 & 2.1 & 16.7 & 11.0 & 7.7 & 12.0 & 7.5 & 12.7 & 13.5 \\
\hline
\end{tabular}

*ZP - the Zmarzły Potok stream below Zmarzły Staw Lake; ** below Czarny Staw Lake; *** below the inflow the strong springs; $* * * *$ reach of stream which dry up temporarily

1 - imago D. latitarsis and D. laticauda; 2 - on sites 1-7 only E. bavarica; 3- on sites 1-6 only B. alpinus, on sites 7-9 B. alpinus and B. melanonyx 


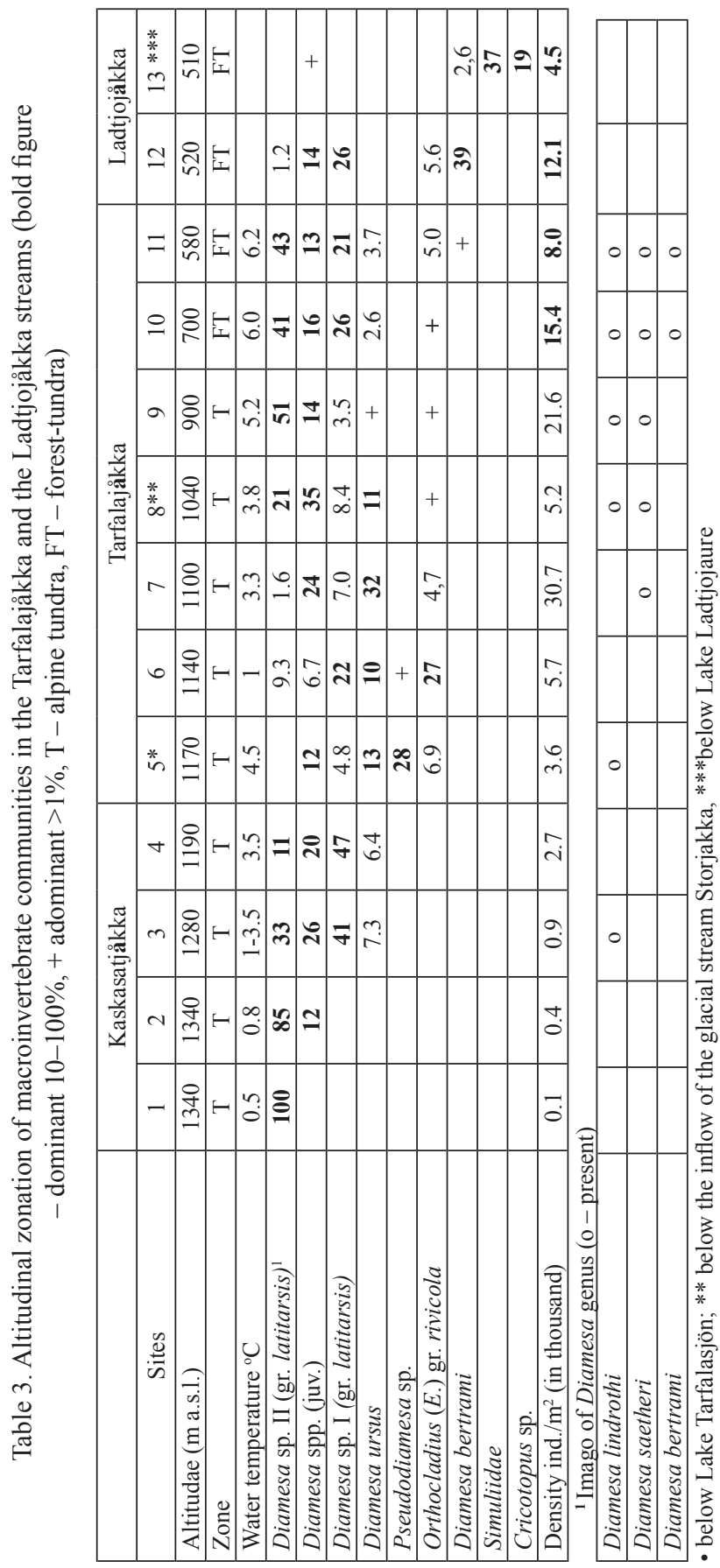


sition and structure of community. Larvae Diamesa ursus, Diamesa sp. II and juvenile stages of Diamesa were dominating. On the consecutive sites 9 to 11 Diamesa sp. I, Diamesa sp. Ii i Diamesa spp. (juv.) were still dominating in the community, but its diversity was bigger and larvae of Orthocladiinae, Simuliidae and other Diptera appeared. However, there were no representatives of other fauna groups.

Above Ladtjojaure Lake the Ladtjojåkka river fauna was similar to that found in Tarfalajåkka stream. Chironomidae from genus Diamesa were dominating. For the first time the single individuals of Ephemeroptera, Plecoptera and Trichoptera were found. Below Ladtjojaure Lake the fauna was completely different. Simuliidae from genus Gnus were dominating. The important components of the fauna were Ephemeroptera, Plecoptera, Trichoptera, Hydracarina, Ostracoda, whereas representatives of taxons dominating so far, like genus Diamesa, appeared, if any, only as sigle individuals.

(III) The Alps streams

An analysis of the fauna's distribution along Rio Plima (Tab. 4) yielded that only single larvae of the genus Diamesa (D. steinboecki, D. sp. II (gr. latitarsis), $D$. sp. (gr. zernyi)) were found at the foot of the glacier. The same community, although consisting of a greater number of specimens, has been observed at the distance $200 \mathrm{~m}$. from the glacier. At the stretch from site $3(300 \mathrm{~m}$ from the glacier) to site 6 the larvae of Diamesa steinboecki were the first dominant. No

Table 4. Characteristics of the Rio Plima river and altitudinal zonation of macroinvertebrate communities (bold figure - dominant 10-100\%, + adominant $>1 \%$, A - alpine zone, F - forest zone)

\begin{tabular}{|l|c|c|c|c|c|c|c|c|c|c|c|}
\hline \multicolumn{1}{|c|}{ Sites } & 1 & 2 & 3 & 4 & 5 & 6 & 7 & $8 *$ & 9 & 10 & 11 \\
\hline \multicolumn{1}{|c}{ Altitudae (m a.s.1.) } & 2700 & 2665 & 2600 & 2500 & 2300 & 2250 & 1900 & 1500 & 1250 & 950 & 670 \\
\hline Zone & $\mathrm{A}$ & $\mathrm{A}$ & $\mathrm{A}$ & $\mathrm{A}$ & $\mathrm{A}$ & $\mathrm{A}$ & $\mathrm{F}$ & $\mathrm{F}$ & $\mathrm{F}$ & $\mathrm{F}$ & \\
\hline Water temperature ${ }^{\circ} \mathrm{C}$ & 0.4 & 3.0 & 4.5 & 4.7 & 7.5 & 6.0 & 4.9 & 11.1 & 10.8 & 11.8 & 17.9 \\
\hline $\mathrm{pH}$ & 8.0 & 7.6 & 7.4 & 7.2 & 7.0 & 6.8 & 6.8 & 7.1 & 7.1 & 7.1 & 7.4 \\
\hline $\mathrm{CO}_{2} \mathrm{mg} / \mathrm{dm}^{3}$ & 0 & 0 & 0 & 0.4 & 0.6 & 1.0 & 1.3 & 1.4 & 1.5 & 1.5 & 1.2 \\
\hline Alkalinity mval/dm $^{3}$ & 0.47 & 0.55 & 0.55 & 0.55 & 0.56 & 0.46 & 0.46 & 0.43 & 0.48 & 0.58 & 0.85 \\
\hline $\mathrm{O}_{2} \mathrm{mg} / \mathrm{dm}^{3}$ & 10.6 & 10.2 & 9.9 & 10.2 & 9.6 & 9.6 & 10.5 & 8.2 & 9.2 & 9.0 & 8.2 \\
\hline $\mathrm{O}_{2} \%$ & 75.7 & 78.2 & 78.9 & 81.8 & 82.7 & 79.6 & 84.6 & 77.0 & 85.8 & 85.9 & 87.7 \\
\hline B.O.D. s mg O,/dm ${ }^{3}$ & 1.60 & 1.90 & 0.85 & 1.40 & 1.30 & 0.65 & 0.90 & 1.90 & 1.30 & 2.20 & 1.90 \\
\hline Diamesa sp. (gr. zernyi) & $\mathbf{5 3}$ & $\mathbf{3 3}$ & $\mathbf{2 0}$ & 7.4 & 9.7 & 7.0 & 3.9 & & & + & + \\
\hline Diamesa steinboecki & $\mathbf{2 6}$ & $\mathbf{2 4}$ & $\mathbf{6 4}$ & $\mathbf{8 4}$ & $\mathbf{3 4}$ & $\mathbf{3 4}$ & 1.2 & & & & \\
\hline Diamesa sp. II (gr. latitarsis) & $\mathbf{1 3}$ & $\mathbf{1 8}$ & & 2.0 & 5.9 & 1.9 & 8.7 & + & & & \\
\hline Diamesa spp. (juv.) & & $\mathbf{2 0}$ & $\mathbf{1 6}$ & 5.4 & 8.4 & 5.8 & 5.1 & + & & & \\
\hline Taeniopterygidae (juv.) & & & & & $\mathbf{1 1}$ & 6.7 & + & & & + & \\
\hline Orthocladius (E.) gr. rivicola & & & & & 7.5 & 1.9 & $\mathbf{2 0}$ & 3.9 & 2.3 & $\mathbf{4 4}$ & $\mathbf{1 3}$ \\
\hline Diamesa sp. I (gr. latitarsis & & & & & & $\mathbf{2 3}$ & $\mathbf{2 0}$ & & & + & + \\
\hline Simulium argenteostriatum & & & & & & & & $\mathbf{5 8}$ & $\mathbf{4 0}$ & 3.4 & + \\
\hline Odagmia monticola & & & & & & & + & & + & $\mathbf{1 2}$ & $\mathbf{6 6}$ \\
\hline Prosimulium sp. & & + & & & + & & & $\mathbf{1 7}$ & + & & \\
\hline Density ind./m ${ }^{2}$ (in thousand) & 0.5 & 1.2 & 2.7 & 1.6 & 1.9 & 0.6 & 8.3 & 3.1 & 2.7 & 2.3 & 8.3 \\
\hline
\end{tabular}

* below Lago Gioveretto reservoir 
fauna groups other than Chironomidae and single larvae of Diptera were found until site 4. Ephemeroptera (Baetis alpinus), Plecoptera and Trichoptera appear at site 5 downstream. The macroinvertebrate community of site 7 (1900 m a.s.1.) is different, the larvae of Orthocladius (Euorthocladius) gr. rivicola were first dominant and taxa diversity much increased at this station. Below the reservoir Gioveretto, Simuliidae (Simulium argenteostriatum and Odagmia monticola) were dominating.

In the glacial stream Rio Gioveretto (Tab. 5), at the foot of the glacier, only single larvae of Diamesa steinboecki and juvenile stage Diamesa were found. A similar community occurred at $300 \mathrm{~m}$. from the glacier, but there its density was higher.. In the middle course of the stream, above the upper forest boundary, Diamesa larvae were dominant and also important was Orthocladius (E.) gr. rivicola. At this site single specimens of Ephemeroptera, Plecoptera and Trichoptera were found. The mayfly Baetis alpinus dominated at the lower course of the stream in the forest zone.

The communities of the spring-fed Rio Madricio were much different (Tab. 5). Already at the spring (station 1), apart from the larvae of the genus Diamesa, fairly numerous were the representatives of other groups; Plecoptera (Protonemura sp.), Trichoptera (Drusus sp.) and Ephemeroptera (Rhithrogena). Downstream from station 2, apart from larvae of Orthocladius (E.) rivicola group and Diame$s a$, the whole stream was also dominated by other taxa. Simuliidae (Prosimulium sp.) were important dominant at station 5 and 6.

(IV) The Caucasus streams

In the stream, just below the glacier, no representatives of the fauna were reported, though numerous imago Diamesa and stoneflies Protonemura alticola

Tab. 5. Altitudinal zonation of macroinvertebrate communities in the glacial stream Rio Gioveretto and spring stream Rio Madricio (symbols as in Tab. 4)

\begin{tabular}{|l|c|c|c|c|c|c|c|c|c|c|c|}
\hline & \multicolumn{9}{|c|}{ Rio Gioveretto } & \multicolumn{7}{c|}{ Rio Madriccio } \\
\hline \multicolumn{1}{|c}{ Sites } & 1 & 2 & 3 & 4 & 5 & 1 & 2 & 3 & 4 & 5 & 6 \\
\hline Altitudae (m a.s.1.) & 2700 & 2650 & 2200 & 2100 & 1900 & 2850 & 2700 & 2600 & 2300 & 2200 & 2000 \\
\hline Zone & $\mathrm{A}$ & $\mathrm{A}$ & $\mathrm{A}$ & $\mathrm{F}$ & $\mathrm{F}$ & $\mathrm{A}$ & $\mathrm{A}$ & $\mathrm{A}$ & $\mathrm{A}$ & $\mathrm{F}$ & $\mathrm{F}$ \\
\hline Water temperature ${ }^{\circ} \mathrm{C}$ & & 6.1 & & 7.2 & & 3.7 & & & & & \\
\hline $\mathrm{pH}$ & & & & 7.1 & & 6.0 & & & & & \\
\hline Diamesa steinboecki & $\mathbf{8 8}$ & $\mathbf{9 0}$ & + & & & & $\mathbf{1 4}$ & & & & \\
\hline Diamesa spp. (juv.) & $\mathbf{1 1}$ & 7.6 & 4.0 & 5.9 & 2.0 & $\mathbf{3 4}$ & 8,4 & 10 & 13 & 14 & 12 \\
\hline Diamesa sp. I (gr. latitarsis) & & + & $\mathbf{5 3}$ & $\mathbf{2 1}$ & & $\mathbf{1 4}$ & $\mathbf{1 2}$ & $\mathbf{2 3}$ & $\mathbf{2 3}$ & $\mathbf{1 5}$ & 6.5 \\
\hline Diamesa sp. II (gr. latitarsis) & & & $\mathbf{2 3}$ & 2.0 & 3.0 & & 8.4 & 2.2 & 5.2 & $\mathbf{1 4}$ & $\mathbf{1 6}$ \\
\hline Baetis alpinus & & & + & $\mathbf{2 2}$ & $\mathbf{4 1}$ & & & & 1.3 & 3.6 & 3.5 \\
\hline Orthocladius (E.) gr. rivicola & & & 8.2 & 7.2 & 7.9 & 2.0 & $\mathbf{2 5}$ & $\mathbf{3 2}$ & $\mathbf{2 1}$ & 3.5 & $\mathbf{1 8}$ \\
\hline Prosimulium sp. & & & + & 2.3 & 2.0 & & 15 & + & 5.2 & $\mathbf{2 8}$ & $\mathbf{1 2}$ \\
\hline Tvetenia sp. & & & + & 6.9 & 3.0 & $\mathbf{2 0}$ & + & 3.0 & 4.3 & 2.3 & 12 \\
\hline Protonemura sp. & & 1,7 & + & & & $\mathbf{1 2}$ & & & + & 1.0 & + \\
\hline Drusus sp. & & & + & 2.3 & + & $\mathbf{1 0}$ & & 6.6 & & & \\
\hline Taeniopterygidae (juv.) & & & & 2.3 & & 1.6 & + & $\mathbf{1 0}$ & 4.6 & 2.6 & + \\
\hline Density ind./m ${ }^{2}$ (in thousand) & 0.2 & 1.5 & 8.0 & 2.0 & 0.5 & 3.0 & 5.0 & 4.0 & 12.0 & 4.7 & 5.3 \\
\hline
\end{tabular}


Tab. 6. Altitudinal zonation of macroinvertebrate communities in the Upper Terek River and its glacial tributories Suatisi (sites 1,2,3) (A - alpine zone, $\mathrm{P}$ - mountain pasture)

\begin{tabular}{|l|c|c|c|c|c|c|c|c|}
\hline \multicolumn{1}{|c|}{ Sites } & 1 & 2 & 3 & 4 & 5 & 6 & 7 & 8 \\
\hline \multicolumn{1}{|c|}{ Altitudae (m a.s.l.) } & 2800 & 2800 & 2750 & 2500 & 2200 & 2100 & 2100 & 1700 \\
\hline Zone & $\mathrm{A}$ & $\mathrm{A}$ & $\mathrm{A}$ & $\mathrm{P}$ & $\mathrm{P}$ & $\mathrm{P}$ & $\mathrm{P}$ & $\mathrm{P}$ \\
\hline Diamesa spp. (juv.) & & $\mathbf{2 9}$ & $\mathbf{1 2}$ & $?$ & + & + & + & + \\
\hline Diamesa sp. (gr. latitarsis) & & $\mathbf{1 6}$ & $\mathbf{4 8}$ & $?$ & $?$ & $?$ & + & + \\
\hline Diamesa spp. & & $\mathbf{2 3}$ & + & $\mathbf{1 5}$ & $?$ & + & + & + \\
\hline Protonemura sp. & & & $\mathbf{1 8}$ & + & $?$ & $?$ & + & + \\
\hline Orthocladius (E.) gr. rivicola & & & + & $\mathbf{2 3}$ & $\mathbf{4 9}$ & $?$ & $\mathbf{?}$ & + \\
\hline Eukiefferiella cyanea & & & & + & $\mathbf{2 0}$ & $\mathbf{7 8}$ & $\mathbf{8 1}$ & $\mathbf{7 5}$ \\
\hline Density ind./m ${ }^{2}$ (in thousand) & 0 & 1.2 & 8.7 & 6.0 & 8.7 & 9.2 & 7.7 & 4.7 \\
\hline
\end{tabular}

were seen flying above the stream (Tab. 6). But already $50 \mathrm{~m}$ below the glacier very young larvae Diamesa were encountered. At a distance of $500 \mathrm{~m}$ from the glacier a community consisting mainly of Diamesa larvae was found. They were hard to identify but on the basis of collected imago at least three species were found: Diamesa caucasica, D. tskhomelidzei, D. sakartvella. Other species, Orthocladius (E.) gr. rivicola dominated in the Terek river at the altitude $2200-2500 \mathrm{~m}$. In the lower part of the Terek river (1700-2200 m) mainly the community consisting of larvae Eukiefferiella cyanea was found.

\section{RESULTS AND DISCUSSION}

Zone of high mountain streams has very characteristic macroinvertebrates communities, which are met in all high mountains and subarctic streams of northern hemisphere (Bretschko 1969, Brodsky 1980, Gay 1982, Kownacka, Kownacki 1972, Kownacki 1991, Maiolini, Lencioni 2001, Robinson at al. 2001, Saether 1968, Steffan 1971, Snook, Milner 2001, Ward 1992, 1994). Examination of the glacial brooks in northern Scandinavia, Steffan (1971) introduced the terms kryal for biotop and kryon for biocenosis. Kryal was divided into two zones: the upper metakryal, with community metakryon dominated by Diamesa, (mainly Diamesa steinboecki group (sensu Kownacki (1978) and Diamesa latitarsi group) and the lower zone hypokryal with community hypokryon inhabited by Prosimulium (Simuliidae) in addition to Diamesa. In both zones Ephemeroptera are absent or very rare. Similar biocenosis were found in streams arising from the permanent snow fields, high mountain lake-outlet stream and temporary springs in high elevations (Kownacka, Kownacki 1972). Metakryon community is common in all investigated streams but hypokryon is not universal and found only in high mountain lake-outlet stream. Hypokryon were found in the outlet of Czarny Staw lake (the Tatra Mts) and in Tarfalajåkka below Lake Tarfalasjön (Scandinavia). In the Alps glacial streams the Rio Plima and Gioveretto me- 
takryon passes into rhithron community. Simuliidae appear in great number only in Rio Plima below Lago Gioveretto reservoir. In the Caucasus metakryon was found in the Suatisi stream. In the lower part of the Terek river (1700-2200 m) mainly the community consisting of larvae Eukiefferiella cyanea was found. This species was characteristic also in the reach of Sucha Woda stream which dries up temporarily at the altitude of about $1000 \mathrm{~m}$ and develops immediately on the resumption of flow (Kownacki 1985). Quite different are macroinvertebrate com-

Table 7. Macroinvertebrate communities in the Olczyskie Wywierzysko spring in seasonal cycle

\begin{tabular}{|l|l|l|l|l|l|l|l|l|l|l|l|}
\hline Month & June & July & Aug. & Oct. & Nov. & Dec. & Jan. & Feb. & Mar. & Apr. & May \\
\hline Water temperature ${ }^{\circ}$ C & 4.1 & 4.5 & 4.8 & 4.5 & 4.4 & 4.4 & 4.0 & 4.3 & 3.8 & 4.0 & 3.9 \\
\hline Parorthocladius nudipennis & 15 & 21 & 51 & 14 & 2 & + & 2 & + & + & + & + \\
\hline Diamesa sp. (gr. zernyi) & 7 & 28 & 3 & 5 & + & & & & & & \\
\hline Baetis alpinus & 9 & 4 & + & 12 & 61 & 69 & 79 & 59 & 53 & 67 & 69 \\
\hline Diamesa sp. (juv.) & 11 & 11 & 16 & 11 & + & + & & + & & & + \\
\hline Protonemura spp. & 11 & + & + & + & + & 11 & 8 & 24 & 25 & 20 & 6 \\
\hline Paratrichocladius skirvithensis & 13 & + & + & + & + & + & 1 & + & 1 & + & \\
\hline Orthocladiinae (juv.) & 11 & 3 & 4 & 9 & 2 & + & 1 & + & + & + & + \\
\hline Diamesa sp. (gr. latitarsis) & 8 & 2 & 5 & 14 & + & + & + & + & + & & + \\
\hline Orthocladius (Euorthocladius) sp. & 2 & 1 & + & 10 & + & & & & & & \\
\hline Eukiefferiella minor & 3 & + & 6 & 3 & 20 & 14 & 1 & 11 & 12 & 4 & 12 \\
\hline Density ind./m ${ }^{2}$ (in thousand) & 22 & 17 & 25 & 7 & 142 & 87 & 52 & 47 & 52 & 42 & 15 \\
\hline
\end{tabular}

Tab. 8. Abiotic factors affecting macroinvertebrate communities in rhitral and kryal zone

\begin{tabular}{|l|l|l|}
\hline & Rhitral & Kryal \\
\hline Feed & spring & $\begin{array}{l}\text { glacier, snow, high mountain lakes, periodic } \\
\text { spring }\end{array}$ \\
\hline Flow & annual & periodic \\
\hline Water level fluctuation & moderate seasonal and low daily & high seasonal and daily \\
\hline Temperature & winter $<4^{\circ} \mathrm{C}<$ summer & $0.5^{\circ} \mathrm{C} \rightarrow 5.5^{\circ} \mathrm{C}$ \\
\hline Conductivity & $>100 \mu \mathrm{S}$ & $10-40 \mu \mathrm{S}$ \\
\hline PH & variable & usually $\leq 7$ \\
\hline Bottom & stable & often mobile (glacial stream) \\
\hline Suspended solids & low & often high (glacial stream) \\
\hline Water transparency & transparent & turbid (glacial streams) \\
\hline
\end{tabular}

Tab. 9. Comparison of rhithron and kryon macroinvertebrate communities

\begin{tabular}{|c|c|c|}
\hline & Rhitron & Kryon \\
\hline Abundance & high & low \\
\hline Diversity & high $(>100$ taxa $)$ & low (1-20 taxa) \\
\hline Domination & $\begin{array}{l}\text { Chironomidae (Orthocladinae } 30-70 \% \text { ) } \\
\text { Ephemeroptera (Baetis, Rhithrogena, } \\
\text { Ecdyonurus) } \\
\text { Plecoptera (Protonemura, Leuctra, } \\
\text { Teniopterygidae) } \\
\text { Trichoptera (Rhyacophila, Drusus, } \\
\text { Allogamus) }\end{array}$ & $\begin{array}{l}\text { Metakryon } \\
\text { domination Diamesa genus (Chironomidae) } \\
\text { Hypokryon = lake outlet } \\
\text { domination Simuliidae + Diamesa } \\
\text { High mountain springbrooks } \\
\text { Diamesa + some taxons characteristics for rhitron } \\
\text { communities, without mayflies } \\
\text { Very often metakryon communities passes directly } \\
\text { into rhithron }\end{array}$ \\
\hline
\end{tabular}


munities of high mountain stream Rio Madricio, originating from spring. Apart from the larvae of the genus Diamesa, fairly numerous were the representatives of other groups; Plecoptera (Protonemura sp.), Trichoptera (Drusus sp.) and Ephemeroptera (Rhithrogena). The similar type of communities was already described (Bretschko 1969). Classification of these communities is difficult. Their character is between that of kryon and rhithron.

The first suggestion was that occurrence of characteristic communities in glacial streams depends on high loads of suspended solids from glacial flour (Steinböck 1934, Dorier 1937). From a synthesis of information on glacial rivers, Milner and Petts (1994) proposed a conceptual model in order to predict the gradient of macroinvertebrate communities in these streams. This model suggests that two principal features, very low temperature, not exciding $4^{\circ} \mathrm{C}$ and channel stability, determine occurrence of kryon community. Also Ward (1994), Hynes (1970) thought that temperature was a dominant ecological feature in kryal. Those factors are important, but not only they decide about the occurrence of kryon communities. In the Mnichowy stream, with transparent water, the same community as in glacial stream was observed. However, in Wywierzysko Olczyskie spring, where the temperature is similar as in glacial stream and oscillating from $3.8^{\circ} \mathrm{C}$ to $4.8^{\circ} \mathrm{C}$ per year, communities were completely different (Tab. 7). It should be agreed that many factors (Tab. 8) have an important influence on the development of kryon communities (Tab. 9).

\section{REFERENCES}

1. Bretschko G. 1969. Zur Hydrobiologie zentralalpine Gletscherabflüsse. Verh. Deutch. Zool. Ges, Innsbruck 1968: 741-750.

2. Brodsky K. A. 1980. Mountain torrent of the Tien Shan. Dr W. Jung, the Hague: 311 pp.

3. Dorier A. 1937. La faune des eaux courantes alpines. Verh. Internat. Verein. Limnol. 8: 33-41.

4. Gay C. 1982. La fauna bentique d'un torrent glaciare des Alpes françaises la Romanche au plan de l'Alpe (Hautes-Alpes). Trav. Lab. Hydrobiol. 71/73: 33-44.

5. Illies J. 1961. Versuch einer allgemein biozönotischen Gleiderung der Flissgewässer. Internat. Revue ges. Hydrobiol. 46: 205-213.

6. Illies J., Botosaneanu L. 1963. Problèmes et méthodes de la classification et de la zonation écologique des eaux courents, considerées surtout du point de vue faunistique. Mitt. Internat. Verein. Limnol. 12: 1-57.

7. Hynes H. B. N. 1970. Ecology of Running Waters. Liverpool University Press, Liverpool.

8. Kownacki A., 1978. Ecology and biogeography of the Diamesa stainboecki group. Acta Univ. Carolinae - Biologica 1-2: 95-102.

9. Kownacki A. 1985. Effect of droughts on the invertebrate communities of high mountain streams. Verh. Internat. Verein. Limnol. 22: 2069-2072.

10. Kownacki A. 1991. Zonal distribution and classification of the invertebrate communities in high mountain streams in South Tirol (Italy). Verh Internat. Verein. Limnol. 24: 2010-2014. 
11. Kownacka M., Kownacki A. 1972. Vertical distribution of zoocenoses in the streams of the Tatra, Caucasus and Balkan Mts. Verh. Internat. Verein. Limnol. 18: 742-750.

12. Maiolini B., Lencioni V. 2001. Longitudinal distribution of macroinvertebrate assemblages in a glacially influence stream system in the Italian Alps. Freshwater Biology 46: 1625-1639.

13. Milner A. M., Petts G. E., 1994. Glacial rivers: physical habitat and ecology. Freshwater Biology, 32: 295-307.

14. Robinson C. T., Uehlinger U., Hieber M. 2001. Spatio-temporal variation in macroinvertebrate assemblages of glacial streams in the Swiss Alps. Freshwater Biology 46: 1663-1672.

15. Saether O. A. 1968. Chironomids of the Finse area, Norway, with special reference to their distribution in a glacier stream. Arch. Hydrobiol. 64: 426-483.

16. Snook D. L., Milner A. M. 2001. The influence of glacial runoff on stream macroinvertebrate communities in Taillon catchment, French Pyrénées. Freshwater Biology 46: 1609-1623.

17. Steffan A. W. 1971. Chironomid (Diptera) biocenoses in Scandinavian glacier brook. Can. Ent. 103: 477-486.

18. Steinböck O. 1934. The Thierwelt der Gletschergewässer. Z. Dt. Österr. Alpenver. 65: 263275.

19. Thienemann A. 1936. Alpine chironomiden (Ergebnnisse von Untersuchungen in der gegend von Garmisch-Partenkirchen, Oberbayern). Arch. Hydrobiol. 30: 176-262.

20. Ward J. V. 1992. Aquatic Insect Ecology. 1. Biology and Habitat. John Wiley \& Sons Inc. New York: 438 pp.

21. Ward J. V. 1994. Ecology of alpine streams. Freshwater Biology 32: 227-294. 